\title{
Association between neighbourhood socioeconomic features and residential fire incidence, related casualties and children: a cross-sectional population-based study in 4 Canadian provinces
}

\author{
Emilie Beaulieu MD, Jennifer Smith BFA, Alex Zheng MSc, Ian Pike PhD
}

\section{Abstract}

Background: This study assessed whether socioeconomic factors affect the rates of residential fire incidence and fire-related injuries and deaths, and whether children are affected differently than the general population.

Methods: We employed a cross-sectional study design using data for British Columbia, Alberta, Manitoba and Ontario from the National Fire Information Database, which includes fire incidents and losses reported by provincial fire marshals across Canada between 2005 and 2015. It also contains 2011 census subdivision social domain data from Statistics Canada based on fire location. Multivariable negative binomial regressions tested the significance of relations between census subdivision socioeconomic factors (average household size, educational attainment, median income and unemployment rate) and the rates of residential fires and casualties per person-year, and casualties per fire incident.

Results: Census subdivisions with higher educational attainment and unemployment rates had higher rates of residential fires (incidence rate ratio [IRR] 1.07, 95\% confidence interval [CI] 1.05-1.10, and IRR 1.24, 95\% Cl 1.18-1.31, respectively) and of residential fire casualties per person-year (IRR $1.09,95 \% \mathrm{Cl} 1.05-1.13$, and IRR 1.29, 95\% Cl 1.20-1.40, respectively). Census subdivisions with smaller average households had higher rates of residential fire casualties per person-year (IRR $0.43,95 \% \mathrm{CI} 0.22-0.83$ ) and per fire incident (IRR $0.75,95 \% \mathrm{Cl} 0.58-0.97$ ), and the association was even stronger for children (IRR $0.17,95 \% \mathrm{Cl} 0.08-0.36$, and IRR $0.41,95 \%$ Cl $0.20-0.86$, respectively).

Interpretation: The results suggest that efforts to prevent residential fires should be prioritized in neighbourhoods with higher educational attainment and unemployment, whereas house fire safety programs should be intensified in neighbourhoods with smaller households to prevent fire casualties, especially among children, once a fire does occur.

lthough important progress has been made in fire safety in recent years, ${ }^{1}$ residential fires cause many deaths and injuries in Canada every year. ${ }^{2-4}$ Some provinces have reported 5-10 deaths per 1 million population and thousands of injuries annually. ${ }^{5-7}$ These traumatic events result in acute and long-lasting suffering - devastating for the individual, the family and the community which renders residential fires an unquestionable public health issue. Because residential fires are largely preventable, ${ }^{8}$ advancing our understanding of the factors that contribute to these events is essential for the effective application of preventive clinical and community interventions. Given the absence of national fire data in Canada until recently, ${ }^{9}$ Canadian research on this topic to date has been limited to individual provinces and has mainly assessed contributing factors such as circumstances of fire and victims' demographic characteristics. $2,3,6,10$
Identifying contributing factors at the population level is also important to guide public health efforts toward house fire safety and effectively prevent residential fire and related injuries and deaths (casualties). According to the US Fire Administration, "socio-economic factors are among the best predictors of fire rates at the neighborhood level."11 Studies from the United States and the United Kingdom ${ }^{11-15}$ showed that socioeconomic deprivation was associated with higher risk of residential fires and related casualties; however, very few Canadian

\section{Competing interests: None declared.}

This article has been peer reviewed.

Correspondence to: Emilie Beaulieu, emilie.beaulieu@bcchr.ca

CMAJ Open 2019. DOI:10.9778/cmajo.20190079 
studies have examined socioeconomic factors contributing to residential fires in recent decades ${ }^{16}$ Given the different welfare state and public policies between countries, ${ }^{17}$ assuming that findings from US and UK studies are generalizable to the Canadian context may lead to erroneous conclusions and ineffective efforts to protect vulnerable populations. Children in particular have been generally overlooked in previous literature examining socioeconomic factors and the risk of injury from residential fires. ${ }^{2,12}$ Additional knowledge about these relations is key to ensuring that house fire safety counselling and prevention programs protect the most vulnerable Canadians, including children.

The purpose of this study was to explore the relation between socioeconomic status and residential fires in Canada; specifically, to determine whether socioeconomic status affects the rates of fire incidence and fire-related casualties, and whether children are affected differently than the general population. A second aim of this study was to assess the effect of socioeconomic status on injury severity.

\section{Methods}

\section{Study design and setting}

We applied a population-based cross-sectional study design to data from the National Fire Information Database (NFID), a demonstration project carried out by the Canadian Association of Fire Chiefs and a division of Statistics Canada, and funded by the Canadian Safety and Security Centre, Defence Research and Development Canada and Public Safety Canada to standardize fire data throughout Canada and enable national analyses and provincial comparisons. The NFID includes 11 years (2005-2015) of microdata information on fire incidents and losses reported by regional fire services to provincial/territorial fire marshals and fire commissioners offices from 6 jurisdictions across Canada (British Columbia, Alberta, Saskatchewan, Manitoba, Ontario and New Brunswick) and the Canadian Armed Forces. The database includes many variables, such as the time and location of the fire, property details, fire protection features, circumstances of the fire and victims' demographic characteristics. It also contains social domain data at the census subdivision and census metropolitan area/census agglomeration levels, provided by the Statistics Canada 2006 census and the 2011 National Household Survey. Additional information pertaining to the NFID has been published previously. ${ }^{16,18}$

\section{Analytic sample}

All residential fires reported by provincial/territorial fire marshals and fire commissioners offices, as well as all casualties that resulted from these residential fires among people of all ages were included in the study. We identified residential fires through the combination of the major occupancy and the property classification variables categorized as "residential." Residential buildings included, but were not limited to, single detached homes, duplexes, semidetached homes, row/garden/ town housing, apartments, tenements, hotels/motels, hostels/ boarding houses and dormitories. The Canadian Armed
Forces and New Brunswick did not provide residential information, and Saskatchewan did not provide socioeconomic data; all 3 were excluded from the study.

\section{Study variables}

Both social and economic characteristics have been shown to influence health and injury risk. ${ }^{19}$ Economic factors studied in the literature usually include income, education and employment, and social factors comprise factors such as social isolation, lone-parent families and size of household. We extracted the following socioeconomic variables at the 2011 census subdivision (neighbourhood) level from the NFID and used them as continuous variables: average number of persons in private households, educational attainment (percentage of population aged $\geq 25$ yr with certificate, diploma or degree), annual median per capita after-tax income, percentage of lone-parent family households and unemployment rate. We categorized age to separate vulnerable populations of interest: 4 years or less (babies), 5-14 years (children), 15-19 years (youth), 20-64 years (adults), and 65 years or more (older adults). Injury severity was based on NFID classification (minor, light, severe) and was dichotomized as minor injury (including both minor and light injury) (hospital stay $<3$ d) and severe injury (hospital stay $\geq 3 \mathrm{~d}$ ).

\section{Statistical analysis}

We calculated rates per person-year by dividing the number of residential fires or casualties by population estimates for census subdivisions. We conducted a collinearity test on socioeconomic variables and subsequently excluded lone parent from the analysis.

Neighbourhoods with a greater number of house fires likely report more fire injuries and deaths. Adjusting house fire casualties for the number of house fire incidents in the neighbourhood (rates of casualties per fire incidents) identifies which socioeconomic factors directly affect the risk of house fire casualties once a fire does occur. We performed 5 different negative binomial regression models to test the strength of the relation between socioeconomic status exposure variables (average number of persons in private households, educational attainment, annual median per capita after-tax income and unemployment rate) and the following outcomes: 1) rate of fire incidents per person-year, 2) rate of casualties per person-year, 3) rate of casualties per person-year among children, 4) rate of casualties per fire incidents and 5) rate of casualties per fire incidents among children. Each model was adjusted for province. We selected negative binomial regression because overdispersion was observed when conducting Poisson models.

Second, we applied a multivariable logistic regression to examine the relation between the 4 socioeconomic status exposure variables and injury severity (severe injury and death v. minor injury), which was set as the binary outcome variable. The model was adjusted for province, age and victim gender.

All tests were 2 -tailed, with significance set at a $p$ value of 0.05. We analyzed the data using SAS University Edition. 


\section{Ethics approval}

Given the secondary use of anonymous data from the NFID, this study was exempted from review by the University of British Columbia/Children's and Women's Health Centre of British Columbia Research Ethics Board.

\section{Results}

From 2005 to 2015, 145252 residential fires and 9952 casualties were reported. Sixty-six fire incidents and 4.5 casualties, including 1.1 casualties among children, occurred per 100000 personyears. The rate of casualties per 1000 fire incidents was 68.5 among the general population and 2.9 among children. Table 1 presents injury severity among subgroups. Of the casualties for whom sex and age were known, the majority were male (4317 [66.2\%]) and adult (5078 [87.5\%]); 6090/9952 (61.2\%) were injured in Ontario. Minor injuries were most common among all subgroups except for adults aged 65 years or more and those in Manitoba, for whom death was more frequent.

Results of the multivariable negative binomial models ${ }^{1-5}$ are presented in Table 2. Model 1 showed that only educational attainment and unemployment rate were significantly associated with the rate of fire incidents per person-year: the rate of fire incidents per person-year increased by $7 \%$ for every $1 \%$ increase in educational level attained (incidence rate ratio [IRR] 1.07, 95\% confidence interval [CI] 1.05-1.10) and by $24 \%$ for every $1 \%$ increase in unemployment rate (IRR 1.24, 95\% CI 1.18-1.31). In model 2, educational attainment and unemployment rate showed similar associations with the rate of casualties per person-year. The average number of persons in private households was significantly associated with the rate of casualties per person-year (IRR 0.43, 95\% CI 0.22-0.83),

\begin{tabular}{|c|c|c|c|c|}
\hline \multirow[b]{2}{*}{ Variable } & \multicolumn{4}{|c|}{ Injury severity; no. (\%) of casualties* } \\
\hline & $\begin{array}{c}\text { Total } \\
n=9952\end{array}$ & $\begin{array}{c}\text { Minor injury } \\
n=7033\end{array}$ & $\begin{array}{c}\text { Severe injury } \\
n=1795\end{array}$ & $\begin{array}{c}\text { Death } \\
n=1124\end{array}$ \\
\hline \multicolumn{5}{|l|}{ Gender } \\
\hline Male & $4317(43.4)$ & $2875(66.6)$ & $734(17.0)$ & $708(16.4)$ \\
\hline Female & $2201(22.1)$ & $1456(66.2)$ & $330(15.0)$ & $415(18.8)$ \\
\hline Missing & $3434(34.5)$ & - & - & - \\
\hline \multicolumn{5}{|l|}{ Age, yr } \\
\hline$\leq 4$ & $112(1.1)$ & $75(67.0)$ & $15(13.4)$ & $22(19.6)$ \\
\hline $5-14$ & $313(3.1)$ & $215(68.7)$ & $59(18.8)$ & $39(12.5)$ \\
\hline $15-19$ & $298(3.0)$ & $202(67.8)$ & $62(20.8)$ & $34(11.4)$ \\
\hline $20-64$ & $4271(42.9)$ & $2875(67.3)$ & $752(17.6)$ & $644(15.1)$ \\
\hline$\geq 65$ & $807(8.1)$ & $336(41.6)$ & $108(13.4)$ & $363(45.0)$ \\
\hline Missing & $4151(41.7)$ & - & - & - \\
\hline \multicolumn{5}{|l|}{ Province } \\
\hline British Columbia & $2059(20.7)$ & $1606(78.0)$ & $196(9.5)$ & $257(12.5)$ \\
\hline Alberta & $1661(16.7)$ & $1259(75.8)$ & $196(11.8)$ & $206(12.4)$ \\
\hline Manitoba & $142(1.4)$ & $32(22.5)$ & $19(13.4)$ & $91(64.1)$ \\
\hline Ontario & $6090(61.2)$ & $4136(67.9)$ & $1384(22.7)$ & $570(9.4)$ \\
\hline \multicolumn{5}{|c|}{ Census subdivision socioeconomic variable, median (5th-95th percentile) } \\
\hline $\begin{array}{l}\text { Average no. of } \\
\text { persons in private } \\
\text { household }\end{array}$ & - & $2.5(2.2-3.1)$ & $2.5(2.2-3.3)$ & $2.5(2.1-3.0)$ \\
\hline $\begin{array}{l}\text { Educational } \\
\text { attainment, \%† }\end{array}$ & - & $82.5(74.74-87.3)$ & $81.04(74.60-87.1)$ & $81.08(68.82-87.1)$ \\
\hline $\begin{array}{l}\text { Annual median per } \\
\text { capita after-tax } \\
\text { income, } \$ 10000 \text { s }\end{array}$ & - & $4.27(3.47-5.6)$ & $4.27(3.60-5.4)$ & $4.22(3.32-5.6)$ \\
\hline $\begin{array}{l}\text { Unemployment } \\
\text { rate, \% }\end{array}$ & - & $7.9(5.2-10.8)$ & $8.4(5.8-10.5)$ & $7.6(4.6-12.2)$ \\
\hline
\end{tabular}


Table 2: Multivariable negative binomial regression results for the relation between 2011 census subdivision* socioeconomic variables and the rate of fire incidents per person-year, the rate of casualties per person-year and the rate of casualties per fire incident

\begin{tabular}{|c|c|c|c|c|c|}
\hline \multirow[b]{2}{*}{ Variable } & \multicolumn{5}{|c|}{ Model; IRR (95\% Cl) } \\
\hline & $\begin{array}{l}\text { 1: Fire incidents per } \\
\text { person-year }\end{array}$ & $\begin{array}{l}\text { 2: Casualties per } \\
\text { person-year }\end{array}$ & $\begin{array}{l}\text { 3: Casualties per } \\
\text { person-year } \\
\text { among those } \\
\text { aged } \leq 14 \mathrm{yr}\end{array}$ & $\begin{array}{c}\text { 4:Casualtiesperfire } \\
\text { incident }\end{array}$ & $\begin{array}{l}\text { 5: Casualties per } \\
\text { fire incident } \\
\text { among those } \\
\text { aged } \leq 14 \mathrm{yr}\end{array}$ \\
\hline \multicolumn{6}{|c|}{ Census subdivision socioeconomic variable } \\
\hline $\begin{array}{l}\text { Average no. of persons } \\
\text { in private household }\end{array}$ & $0.75(0.50-1.15)$ & $0.43(0.22-0.83)$ & $0.17(0.08-0.36)$ & $0.75(0.58-0.97)$ & $0.41(0.20-0.86)$ \\
\hline Educational attainment & $1.07(1.05-1.11)$ & $1.09(1.05-1.13)$ & $0.96(0.93-1.00)$ & $1.01(0.99-1.02)$ & $0.99(0.95-1.02)$ \\
\hline $\begin{array}{l}\text { Annual median per } \\
\text { capita after-tax income }\end{array}$ & $0.95(0.86-1.06)$ & $0.92(0.78-1.09)$ & $1.22(0.96-1.54)$ & $1.04(0.95-1.13)$ & $1.25(0.98-1.60)$ \\
\hline Unemployment rate & $1.24(1.18-1.31)$ & $1.29(1.20-1.40)$ & $1.01(0.93-1.10)$ & $1.02(0.99-1.05)$ & $1.00(0.91-1.09)$ \\
\hline \multicolumn{6}{|c|}{ Province (reference = British Columbia) } \\
\hline Ontario & $18.90(13.90-25.75)$ & $19.80(12.60-30.90)$ & $0.59(0.36-0.95)$ & $0.97(0.80-1.16)$ & $0.54(0.36-0.80)$ \\
\hline Manitoba & $7.02(4.12-11.70)$ & $1.91(0.79-4.60)$ & $0.48(0.16-1.50)$ & $0.22(0.14-0.35)$ & $0.36(0.14-0.92)$ \\
\hline Alberta & $4.51(2.85-6.88)$ & $6.38(3.33-12.20)$ & $0.82(0.41-1.63)$ & $1.32(1.01-1.72)$ & $1.32(0.77-2.27)$ \\
\hline
\end{tabular}

Table 3: Multivariable logistic regression results for the relation between injury severity* and 2011 census subdivision socioeconomic variables $†$

\begin{tabular}{|c|c|}
\hline Variable & $\begin{array}{l}\text { Multivariable OR } \\
\qquad(95 \% \mathrm{Cl})\end{array}$ \\
\hline \multicolumn{2}{|l|}{ Census subdivision socioeconomic variable } \\
\hline $\begin{array}{l}\text { Average number of persons in private } \\
\text { household }\end{array}$ & $0.80(0.66-0.97)$ \\
\hline Educational attainment & $0.96(0.95-0.97)$ \\
\hline $\begin{array}{l}\text { Annual median per capita after-tax } \\
\text { income }\end{array}$ & $1.09(0.98-1.21)$ \\
\hline Unemployment rate & $0.99(0.96-1.21)$ \\
\hline Female sex (ref = male sex $)$ & $1.12(1.02-1.25)$ \\
\hline \multicolumn{2}{|l|}{ Age, yr (ref = 20-64) } \\
\hline$\leq 4$ & $0.98(0.65-1.49)$ \\
\hline $5-14$ & $0.80(0.62-1.04)$ \\
\hline $15-19$ & $1.01(0.77-1.31)$ \\
\hline$\geq 65$ & $2.95(2.51-3.47)$ \\
\hline Unknown & $0.37(0.33-0.42)$ \\
\hline \multicolumn{2}{|l|}{ Province $($ reference $=$ British Columbia) } \\
\hline Ontario & $2.46(2.10-2.87)$ \\
\hline Manitoba & $7.88(5.13-12.10)$ \\
\hline Alberta & $0.85(0.70-1.03)$ \\
\hline \multicolumn{2}{|c|}{$\begin{array}{l}\text { Note: } \mathrm{Cl}=\text { confidence interval, } \mathrm{OR}=\text { odds ratio. } \\
\text { *Defined as a binary variable: severe injury and death versus minor injury. } \\
\text { †Results based on } 9228 \text { people. }\end{array}$} \\
\hline
\end{tabular}

with an even stronger relation for children, as shown in model 3. For every 1-person increase in the average number of persons in private households, there was an $83 \%$ decrease in the rate of casualties per person-year among children aged 14 years or less (IRR 0.17 , 95\% CI 0.08-0.36). In model 4, only the average number of persons in private households showed a significant relation with the rates of casualties once a fire occurred: for every 1-person increase in the average number of persons in private households, the risk decreased by 25\% (IRR 0.75, 95\% CI 0.58-0.97); the relation was stronger for children aged 14 years or less than among the general population (model 5) (IRR 0.41, 95\% CI 0.20-0.86).

Multivariable logistic regression showed that, for every 1 -person increase in the average number of persons in private households, the odds of death and severe injury (v. minor injury) decreased by $20 \%$ (odds ratio [OR] $0.80,95 \%$ CI $0.66-0.97$ ) (Table 3). For every $1 \%$ increase in educational level attained, the odds of death and severe injury decreased by 4\% (OR 0.96, 95\% CI 0.95-0.97).

Income was not significantly associated with any outcomes.

\section{Interpretation}

We found that neighbourhoods with higher educational attainment and unemployment rate experienced higher rates of residential fires and fire-related casualties. However, when assessing the rates of casualties once a fire does occur, educational attainment and unemployment no longer affected the relation. In addition to being associated with casualty rates per person-year, average household size was the only socioeconomic status variable associated with the rates of casualties per 
fire incident. Smaller household size was the only socioeconomic status variable to influence the risk of casualty once a fire occurred, and this association was even stronger for children. This is concerning, given the considerable decline of the average household size in Canada in recent decades. ${ }^{20}$ Our results also showed that neighbourhoods with larger average household size and higher educational attainment had lower odds of severe injury and death compared to minor injury. Income was not associated with residential fires, casualties or injury severity.

Although the literature suggests that socioeconomic deprivation increases the risk of fire incidents and related casualties overall, ${ }^{11,15,21}$ mixed findings across studies render the association between educational attainment, residential fire incidents and casualties inconclusive. ${ }^{21,22}$ However, 2 recent studies showed that higher level of education was associated with increased risk of residential fire incidents, ${ }^{23,24}$ consistent with our findings. Our results for employment status are consistent with those of previous studies. ${ }^{21,22,25}$ Although the absence of a relation between income and risk of residential fire incidents and casualties was surprising, recent studies have also shown no association..$^{23,24,26}$ This may be explained by various financial support and fire safety programs delivering free smoke detectors and education, which may limit the influence of poverty on some risk factors for residential fires in Canada, but additional studies are needed.

Previous investigators also found that household size was not associated with risk of fire incidents. ${ }^{21,23,24}$ However, the literature is sparse regarding the strength of the relation between household size and fire casualty rates. Studies have shown that people living alone who were alone at the time of a fire and lone-parent households were at increased risk for residential fire injuries and deaths, ${ }^{16,25,27,28}$ consistent with our finding regarding small household size and increased rates of fire casualties once a fire occurs. Nonetheless, neighbourhoods with a predominance of smaller households have seldom been examined and reported as indicators of populations at high risk for residential-fire-related casualties. Although recent studies in low- and middle-income countries have reiterated overcrowding as a risk factor for residential fire casualties, ${ }^{29,30}$ this association has not been shown in Canada among the general population. ${ }^{31}$ Household overcrowding, defined as a people per room ratio above 1 , is reported in only $3 \%$ of the Canadian population. ${ }^{32}$ Given that the neighbourhood average number of persons in private households included in this study ranged between 1.8 and 4.4, it likely did not meet household overcrowding criteria, which may explain why no association between residential fire and overcrowding was observed. To our knowledge, no other ecological studies have adjusted the risk of casualties by fire incidents, which limits comparisons to our results.

Additional research with individual-level data is essential to confirm our results, particularly as they apply in the Canadian context. Further studies are needed to clarify the impact of income on residential fire casualties and to understand why neighbourhoods with high educational attainment have higher rates of residential fires and casualties. The influence of average household size on fire-related casualty risk should also be further investigated. We hypothesize that help may be more readily available in neighbourhoods with larger average household size, thereby reducing the likelihood of injuries and deaths regardless of the presence of a house fire safety plan. In neighbourhoods with smaller households, the house fire safety plan may mediate this relation as the only tool available at the time of a fire to escape and to avoid potential injuries or death. Further investigation could inform practical actions to reduce the increased risk of fire casualties in neighbourhoods with a predominance of smaller households.

\section{Limitations}

Not all provinces provided socioeconomic or residential data in the NFID; only 4 provinces were included in our final analyses. Not all fire services provided consistent data for some variables, with possible underreporting of residential fire incidents and casualties. Among the 4 provinces included in this study, there were almost no missing data for residential fire incidence, casualties and socioeconomic factors, but age and gender were unknown for more than a third of victims. However, these cases were still included in the final logistic model as a separate age and gender category. Missing age data resulted in inclusion of a small number of casualties in the negative binomial regression for children, which may have affected the measure of association toward the null. Second, the NFID used hospital length of stay to categorize injury severity, which may limit the validity of this variable. Tables 1 and 3 should be interpreted with caution. Third, because the socioeconomic data used were provided at the census subdivision level, inference cannot be made at the individual level (ecological fallacy). ${ }^{33}$ Associations may not be observable between neighbourhoods if household socioeconomic conditions are heterogeneous among neighbourhoods. Moreover, they may be influenced by mediators that were not directly assessed through our study, such as type of building, and proportion of refugee and immigrants living in the neighbourhood.

\section{Conclusion}

By estimating rates of fire casualties per fire incident, our study identifies which neighbourhood socioeconomic factors influence the risk of being injured or killed in a house fire, after adjustment for neighbourhood residential fire rates. In the context of fiscal constraint, the study provides evidence to intensify residential fire prevention in neighbourhoods with higher educational attainment and unemployment rates and to prioritize education programs regarding house fire safety in areas with a predominance of smaller households, including neighbourhoods with single-parent families. Physicians working in identified high-risk neighbourhoods can contribute by including systematic fire prevention and safety counselling about a smoke-free house, matches and lighter safety, fire escape plans and smoke alarms during patient visits. Our findings emphasize the importance of acknowledging the differences between children and adults, and physicians and public health practitioners are ideally positioned to support 
prevention efforts through direct counselling and through collaboration with schools and other agencies to regularly develop and integrate fire prevention activities.

\section{References}

1. Rohde D, Corcoran J, Sydes M, et al. The association between smoke alarm presence and injury and death rates: a systematic review and meta-analysis. Fire Saf 7 2016;81:58-63.

2. BC Coroners Service Child Death Review Panel: a review of fire-related deaths in children and youth 2005-2014: report to the Chief coroner of British Columbia. Victoria: British Columbia Ministry of Health; 2016. Available: www2.gov.bc.ca/assets/gov/birth -adoption-death-marriage-and-divorce/deaths/coroners-service/child-death-review -unit/reports-publications/fire-related-deaths-children-youth.pdf (accessed 2018 Aug. 16).

3. Chernichko L, Saunders LD, Tough S. Unintentional house fire deaths in Alberta 1985-1990: a population study. Can F Public Health 1993;84:317-20.

4. Clare J, Kelly H. Fire and at risk populations in Canada: analysis of the Canadian National Fire Information Database. Abbotsford (BC): Centre for Criminal Justice Research; 2017. Available: https://cjr.ufv.ca/wp-content/uploads/2018/04/ Murdoch-University-Fire-and-at-Risk-Populations.pdf (accessed 2018 Nov. 19).

5. Alberta Emergency Management Agency. 2009 Alberta Fire Commissioner's statistical report. Edmonton: Alberta Health; updated 2015 May 15. Available: https:// open.alberta.ca/dataset/04a21ab2-c7dc-4063-84a6-4481be5e4165/resource/2b365 a7d-ce83-45e4-ac43-4700df246b38/download/745300-2009-fire-commissioner -statistical-report-aema.pdf (accessed 2018 Nov. 18).

6. BC Coroners Service, Ministry of Justice. Residential structure fire deaths in $B C$, 2007-2011. Victoria: British Columbia Ministry of Health; 2012. Available: www2.gov.bc.ca/assets/gov/birth-adoption-death-marriage-and-divorce/deaths/ coroners-service/statistical/fire.pdf (accessed 2018 Aug. 17).

7. Office of the Fire Marshal and Emergency Management. Ontario fatal fires: fire death rate. Toronto: Ministry of the Solicitor General; revised December 2017. Available: www.mcscs.jus.gov.on.ca/english/FireMarshal/Media RelationsandResources/FireStatistics/OntarioFatalities/FireDeathRate/stats_ death_rate.html (accessed 2018 Dec. 5).

8. Warda L, Tenenbein M, Movatt MEK. House fire injury prevention update. Part II. A review of the effectiveness of preventive interventions. Inj Prev 1999; 5:217-25.

9. Canadian Centre for Justice Statistics. Fire statistics in Canada: selected observations from the National Fire Information Database 2005 to 2014. Ottawa: Canadian Association of Fire Chiefs; 2017. Available: http://nfidcanada.ca/wp -content/uploads/2017/09/Fire-statistics-in-Canada-2005-to-2014.pdf (accessed 2018 Aug. 17).

10. Chen YA, Bridgman-Acker K, Edwards J, et al. Pediatric fire deaths in Ontario: retrospective study of behavioural, social and environmental risk factors. Can Fam Physician 2011;57:e169-77.

11. National Fire Data Center, United States Fire Administration, Federal Emergency Management Agency. Socioeconomic factors and the incidence of fire. Emmitsburg (MD): U.S. Fire Administration; 1997. Available: www.usfa.fema.gov/ downloads/pdf/statistics/socio.pdf (accessed 2018 Sept. 27).

12. Istre GR, McCoy M, Carlin DK, et al. Residential fire related deaths and injuries among children: fireplay, smoke alarms, and prevention. Inj Prev 2002;8:128-32.

13. Shai D. Income, housing, and fire injuries: a census tract analysis. Public Health Rep 2006;121:149-54.

14. Istre GR, McCoy MA, Osborn L, et al. Deaths and injuries from house fires. $N$ Engl 7 Med 2001;344:1911-6.

15. Mulvaney C, Kendrick D, Towner E, et al. Fatal and non-fatal fire injuries in England 1995-2004: time trends and inequalities by age, sex and area deprivation. 7 Public Health (Oxf) 2009;31:154-61.

16. Smith J, Dhinsa A, Rajabali F, et al. The epidemiology of residential fires among children and youth in Canada. Vancouver: BC Injury Research and Prevention Unit; 2018. Available: www.injuryresearch.bc.ca/wp-content/uploads/2018/03/ UBC-IAN-PIKE-NFID_Report_0220181.pdf (accessed 2018 May 15).

17. Alesina A, Glaeser EL. Why are welfare states in the US and Europe so different? Horizons Stratégie 2:51-61. Available: www.cairn.info/revue-horizons -strategiques-2006-2-page-51.htm\# (accessed 2019 May 15).
18. National Fire Information Database (NFID) data dictionary. Ottawa: Canadian Association of Fire Chiefs; 2017. Available: http://nfidcanada.ca/wp-content/ uploads/2017/09/NFID-Data-Dictionary_final.pdf (accessed 2019 May 16).

19. Marmot M, Goldblatt P, Allen J, et al. Fair society, healthy lives (the Marmot Review). London (UK): Institute of Health Equity, Department for Epidemiology \& Public Health, University College London; 2010. Available: www. instituteofhealthequity.org/resources-reports/fair-society-healthy-lives-the -marmot-review/fair-society-healthy-lives-full-report-pdf.pdf (accessed 2019 Feb. 7).

20. The shift to smaller households over the past century. Ottawa: Statistic Canada; modified 2018 May 17. Available: www150.statcan.gc.ca/n1/pub/11-630-x/11 -630-x2015008-eng.htm (accessed 2018 Dec. 6)

21. Turner SL, Johnson RD, Weightman AL, et al. Risk factors associated with unintentional house fire incidents, injuries and deaths in high-income countries: a systematic review. Inj Prev 2017;23:131-7.

22. Barnett ML. Risk factors and incidence of residential fire experiences reported retrospectively [thesis]. Melbourne (Australia): Victoria Universiy; 2008. Available: http://vuir.vu.edu.au/1987/1/Michelle_Barnett_PhD_Final_Copy.pdf (accessed 2018 Nov. 19)

23. Nilson F, Bonander C, Jonsson A. Differences in determinants amongst individuals reporting residential fires in Sweden: results from a cross-sectional study. Fire Technol 2015;51:615-26.

24. Greene MA. Comparison of the characteristics of fire and non-fire households in the 2004-2005 survey of fire department-attended and unattended fires. Inj Prev 2012;18:170-5.

25. Xiong L, Bruck D, Ball M. Comparative investigation of 'survival' and fatality factors in accidental residential fires. Fire Saf 7 2015;73:37-47.

26. Perry EC, Shields WC, O'Brocki R, et al. Examining fire department injury data as a tool for epidemiological investigation. 7 Burn Care Res 2015;36:310-4.

27. Marshall SW, Runyan CW, Bangdiwala SI, et al. Fatal residential fires: Who dies and who survives? $7 A M A$ 1998;279:1633-7.

28. Runyan CW, Bangdiwala SI, Linzer MA, et al. Risk factors for fatal residential fires. N Engl F Med 1992;327:859-63.

29. Edelman LS. Social and economic factors associated with the risk of burn injury. Burns 2007;33:958-65.

30. Delgado J, Ramírez-Cardich ME, Gilman RH, et al. Risk factors for burns in children: crowding, poverty, and poor maternal education. Inj Prev 2002;8: 38-41.

31. Canadian housing fire statistics: external research program. Ottawa: Canada Mortgage and Housing Corporation; 2004. Available: http://publications.gc. ca/collections/collection_2011/schl-cmhc/nh18-1-2/NH18-1-2-137-2004-eng. pdf (accessed 2018 Nov. 21).

32. Pepin C, Muckle G, Moisan C, et al. Household overcrowding and psychological distress among Nunavik Inuit adolescents: a longitudinal study. Int 7 Circumpolar Health 2018;77:1541395

33. Idrovo AJ. Three criteria for ecological fallacy. Environ Health Perspect 2011; 119:A332.

34. Gielen AC, Shields W, Frattaroli S, et al. Enhancing fire department home visiting programs: results of a community intervention trial. 7 Burn Care Res 2013; 34:e250-6.

Affiliations: BC Injury Research and Prevention Unit (Beaulieu, Smith, Zheng, Pike); Department of Pediatrics (Beaulieu, Pike), University of British Columbia, Vancouver, BC

Contributors: Emilie Beaulieu and Alex Zheng conceived of and designed the study and analyzed the data. Alex Zheng and Jennifer Smith contributed to the interpretation of the data. Emilie Beaulieu drafted the manuscript, and Alex Zheng, Jennifer Smith and Ian Pike critically revised it for important intellectual content. Ian Pike supervised the study. All of the authors approved the version to be published and agreed to be accountable for all aspects of the work.

Supplemental information: For reviewer comments and the original submission of this manuscript, please see www.cmajopen.ca/content/7/3/ E562/suppl/DC1. 